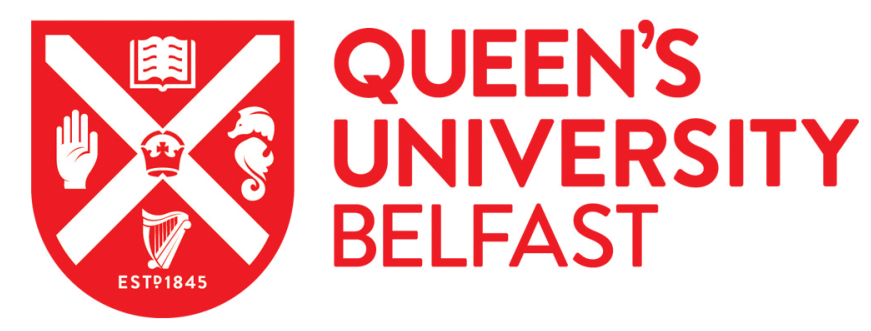

\title{
Globalization and the spread of capitalism: material resonances
}

Horning, A., \& Schweickart, E. (2016). Globalization and the spread of capitalism: material resonances. PostMedieval Archaeology, 50(1), 34-52. https://doi.org/10.1080/00794236.2016.1169490

\author{
Published in: \\ Post-Medieval Archaeology
}

Document Version:

Peer reviewed version

Queen's University Belfast - Research Portal:

Link to publication record in Queen's University Belfast Research Portal

\section{Publisher rights}

(c) Society for Post-Medieval Archaeology 2016.

This work is made available online in accordance with the publisher's policies. Please refer to any applicable terms of use of the publisher.

\section{General rights}

Copyright for the publications made accessible via the Queen's University Belfast Research Portal is retained by the author(s) and / or other copyright owners and it is a condition of accessing these publications that users recognise and abide by the legal requirements associated with these rights.

Take down policy

The Research Portal is Queen's institutional repository that provides access to Queen's research output. Every effort has been made to ensure that content in the Research Portal does not infringe any person's rights, or applicable UK laws. If you discover content in the Research Portal that you believe breaches copyright or violates any law, please contact openaccess@qub.ac.uk. 
Globalisation and the Spread of Capitalism: Material Resonances

Audrey Horning (Queen's University Belfast) and Eric Schweickart (University of Tennessee)

Word count (including notes and bibliography):

Abbreviated title: Globalisation and capitalism

Revised final manuscript submitted: 25 January 2016

Address for correspondence:

Professor Audrey Horning

School of Geography, Archaeology and Palaeoecology

Queen's University Belfast

Belfast BT7 1NN

Northern Ireland

a.horning@qub.ac.uk 

Globalisation and the Spread of Capitalism: Material Resonances

\section{By AUDREY HORNING and ERIC SCHWEICKART}

SUMMARY: The intertwined processes of globalisation and capitalism are fundamentally material in expression and are central to understandings of the modern world (however defined). Over the last fifty years, post-medieval archaeologists have engaged directly with the materiality of these broad-scale processes: initially from the standpoint of empiricallydriven descriptive studies, and latterly to more interpretative approaches which challenge and stretch disciplinary boundaries. As later historical archaeology is increasingly characterised by a theoretically and geographically diverse set of practices, insights into the material resonances of globalisation and capitalism have become increasing sophisticated and more broadly relevant to the present day.

\section{INTRODUCTION}

Considerations of globalisation and capitalism fundamentally underpin understandings of the post-medieval world. The movement of ideas, goods and people, while always part of the human experience, markedly accelerated from the 15th century onwards, influenced by maritime technological advancements and the emergence of new forms of exchange relations and understandings of alienability, abstraction, and commoditisation that supported and defined colonial expansion. Since the first issue of Post-Medieval Archaeology in 1967, scholars publishing in the journal have explored the ramifications of capitalism and globalisation by examining their material signatures and highlighting the manner in which the emergence of modernity was fundamentally material in character. In more recent years, scholarship has focused overtly upon the cultural impacts of capitalism and globalisation, as the discipline of post-medieval/later historical archaeology more generally has expanded to become truly global in content and context, as well as more explicitly theorised.

As many commentators have noted, post-medieval archaeology in its formative years developed a reputation for grounded, empirical studies of objects, buildings, and landscapes: in essence, studying the products rather than the processes of capitalism. ${ }^{1}$ Rich 
in detail and content, these studies tended to eschew application of the broader interpretive frameworks more readily embraced by anthropological colleagues across the Atlantic. Capitalism in particular has long provided a guiding interpretive framework for North American historical archaeology, to the extent that the discipline has often been labelled the archaeology of capitalism ${ }^{2}$. By contrast, it would not be until the 21st century that the term capitalism or capitalist began to appear with any regularity within articles in Post-Medieval Archaeology, with only a handful of appearances in the 1980s and 1990s (principally in the reference list rather than in the text) ${ }^{3}$, and none at all in the 1960s and 1970s. In fact, the original accepted timeframe for post-medieval archaeology saw it ending with the advent of industrialism, and by extension the rise of managerial capitalism.

More precisely, as suggested by Lawrence Butler in the opening editorial of the first issue of Post-Medieval Archaeology, the period of interest for the Society for Post-Medieval Archaeology ended with 'the opening of Josiah Wedgwood's factory at Etruria'. ${ }^{4}$ This event is perhaps the best known example of the emergence of industrial capitalism, complete with Wedgwood's innovative rationalised production system, but it is a surprising cut-off date for a society that had emerged from a specialist ceramics study group, and at odds with the interests of later historical archaeologists today. The Stoke pottery industry and its considerable archaeological, architectural, and documentary legacies subsequently supported a wide range of fruitful studies not only into processes of pottery manufacture and the global distribution of Staffordshire wares, but also into the daily lives and experiences of all those working in the potteries, related industries (such as flint mills) and along the transportation networks, including canals, railways, and roads, which were integral to the industry's success. ${ }^{5}$

Industrial capitalism may have originally been off limits, but what of the reordering of the landscape via agrarian capitalism, or the mercantile capitalism, whose seeds were first sewn in Renaissance Italy, that began to knit the world together from the 15th century? While one finds few overt references to capitalism itself in scholarship published in the journal in the 1960s-1980s, we would argue that these foundational studies nonetheless contributed measurably to our understandings of the importance of the transition from feudal to mercantile economies that have latterly informed more interpretive, synthetic studies. By way of example, it would be impossible to discuss either the economic penetration or 
cultural ramifications of the tobacco trade without utilising the painstaking research into clay tobacco pipe bowl chronology, stem bore analysis and maker's marks undertaken in these early publications. ${ }^{6}$ As early as 1969, Adrian Oswald noted how the re-export of tobacco from Plymouth to the Netherlands in the early 17th century was reflected in the presence of Dutch pipes in Plymouth assemblages as well as the emergence of locally-made pipes after the Dutch fashion, thereby using the accumulated knowledge about international pipemaking styles to comment on the fierce competition between the Dutch and the English over tobacco markets. ${ }^{7}$

As all the authors in this special edition highlight, post-medieval archaeology has evolved and broadened its focus to include a wide range of interpretative frameworks and embrace more diverse theoretical perspectives. Given that both of us practice historical/ postmedieval archaeology on both sides of the Atlantic and have been trained in both American and European approaches, we argue that the unique datasets and perspectives of postmedieval archaeology, particularly as expressed on the pages of this journal over the last fifty years, is of considerable value in complementing North American scholarship by similarly challenging and complicating how we deal with capitalism and globalisation. That said, post-medieval archaeology still exhibits a tendency to focus on the 'small-scale and the local' rather than striving for multiscalar analyses, as observed by Matthew Johnson in a 2006 overview. $^{8}$ In this article we highlight both studies that do engage broadly while also seeking to highlight the value and potential of microscale studies to contribute to debates over capitalism colonialism, and globalisation more broadly.

\section{CAPITALISM AND POST-MEDIEVAL ARCHAEOLOGY}

Capitalist behaviours did not emerge anew immediately in the wake of the Columbian venture, traditionally taken as the start date for historical archaeology, but clearly have much older and deeper roots in medieval Europe. ${ }^{9}$ While recognition of this time depth is hardly new, there have been relatively few efforts to critically examine the relationship between medieval and post-medieval European political economies from an archaeological point of view that could complement the growing number of studies that are engaging with the complexities of non-European socioeconomic formulations and their concomitant influence on colonial societies. ${ }^{10}$ Moreover, any presumptions about the totalising character 
of capitalism, and the attendant Improvement ethic, are challenged by evidence from Europe where non-capitalist exchange practices and cultural behaviours persist well into the 19th century, the result not of geographic isolation, but of local circumstances and priorities. ${ }^{11}$ In fact, what emerges from a consideration of the last fifty years of scholarship in post-medieval archaeology is the remarkable diversity of people's experiences of the changes wrought by the forces of capitalism and nascent globalisation. While clearly no one was unaffected by the major socio-political and economic changes attendant upon the emergence of capitalism, its grasp was neither immediate nor complete. Nor were individuals, families, and communities wholly powerless in the face of these changes. Surprising insights have arisen from an array of both urban and rural archaeological case studies that highlight the ways in which different social groups endeavoured to control their engagement with changing market forces.

Broadly defined, capitalism is an economic system in which the means of production are held and funded privately in order to generate further profit. Those who cannot afford to invest instead sell their labour in return for wages. Labour thus becomes an alienable commodity- something with an exchange value- distinguishing labour relations from those of a feudal economy, whereby a set of mutual obligations knit together labourers and landowners. Increasingly, land, resources and nature itself became commodified with uniform systems of measurement and valuation. However, the emergence of agrarian capitalism, traditionally marked in England by the enclosing of fields and shift towards intensified pastoralism, was a long, gradual, and even incomplete process. The sporadic and piecemeal nature of enclosure in particular is thrown into sharp relief by archaeological studies, as argued by Richard Newman, challenging the traditional perspective from economic history of a relatively straightforward process of transition. ${ }^{12}$

While some English lands were enclosed as early as the 15th century to increase production and profitability linked to the wool trade, others remain as open fields today, as at Laxton in Nottinghamshire. In Northumberland, sporadic enclosure throughout the seventeenth and eighteenth centuries resulted in the wholesale reordering and effective abandonment of medieval villages such as Clarewood and east Matfen by 1702, the results of improving activities by an entrepreneurial landowner. ${ }^{13}$ Agrarian capitalism must also be understood within the context of the philosophy of improvement more generally, a topic that has been 
very productively explored through an archaeological lens. The ethos of Improvement, defined as 'a cross-cutting ethic, directed not only at the improvement of agricultural production... but also at the moral, intellectual and physical improvement of the self, of the labouring people, of society, of production and of the human environment' shaped the material remains of buildings, institutions, burials, landscapes and settlements. ${ }^{14}$

The principles of the Improvement ideology played out on the landscape in often highly contentious ways. The controversial clearances of parts of the Scottish highlands and islands, still strongly resonant in local memory, are marked by clusters of abandoned dwellings in the rural landscape. One such example, the site of Arichonan (Fig. 1) on the slopes of Gleann a' Ghaolbhan in North Knapdale, is now a scheduled ancient monument consisting of a cluster of ten ruinous houses accompanied by sheep fanks, enclosures and laneways. The inhabitants of this township, first settled sometime before the close of the 17th century, were evicted from their homes on the Poltalloch Estate to make way for sheep. Homes and gardens were repurposed to house the stock, and an improving landlord had a new dwelling constructed within the settlement for the shepherd. In stark contrast to the single story, cruck-roofed stone dwellings that housed the township's families, the shepherd's house was two storeys in height, its doors and windows detailed with schist, and heated by a fully enclosed gable end chimney. ${ }^{15}$

There is no doubt that the enforced reordering of the Arichonan landscape and countless others to suit the needs of agrarian capitalism, morally justified through the Improvement ethic, was a culturally disruptive process. However, it would be folly to simply present the inhabitants of regions like the Scottish Highlands as either pawns of external economic forces, or as somehow previously immune to change. Resistance to capitalist formulations in the British Isles is not hard to identify, as convincingly argued by Bill Frazer, James Symonds, and Charles Orser. ${ }^{16}$ However, such actions also must be understood through critical consideration of local historical contexts which more often than not challenges stark constructions of domination and resistance as the primary impacts of capitalism. As demonstrated by Chris Dalglish, interpretations of Highland society as static and traditional prior to the period of the clearances is fundamentally ahistorical and ignores considerable evidence for reordering of landed estates and Highland society more generally from at least the 16 th century onwards. The increasing quantification and commodification of land can be 
read not only in the fencing of fields and clearing of forests, but also in elite architecture. The addition of viewing galleries to Highland castles, starting around 1550, reflects 'the beginnings of a new attitude to landscape, reconceived as commodity, as something not lived, but objectified from a distance. ${ }^{17}$ Changes in the interior of Highland castles mirror the same contemporary movement toward privacy through the elimination of open halls and the division of space that Matthew Johnson has termed closure and identified as occurring in the south of England in the same period. ${ }^{18}$

The extent to which such ideas permeated all levels of society remains a topic of some debate. For decades archaeologists have pointed to the continuing production of hand built coarse earthenware pottery, known as craggan ware, in parts of the western Isles as indicative of cultural conservatism and isolation, given that the form has its origins in the Iron Age. ${ }^{19}$ But pottery makers do not operate in a void. Even in a barter economy, craft producers rely upon demand. For self-aware Hebridean potters in the 19th century, demand more often than not came from 'outsiders' seeking a piece of 'authentic' tradition, while they also adapted their practices to new ideas, as made abundantly clear in an observation made by Arthur Mitchell on a visit in 1863: 'Expecting a visit from curious strangers, proud of her skill, and anxious to display it, our Barvas potter had prepared for us, in addition to the craggans, some imitations of Staffordshire ware, and some models of animals. ${ }^{20}$ Continuity of material practices may be as much a matter of conscious choice in the face of alternatives as it is evidence of the incomplete penetration of capitalist forces. Disentangling the commodification of Highland identity in the 18th and 19th century from the actualities of individual and community experience remains key to understanding the extension of capitalism and Enlightenment ideologies to all levels of society.

Dalglish's study reveals that Highland elites were just as influenced by Renaissance architecture and ideologies as were their contemporaries in England. But it was not only new architectural fashions and changing understandings of land as a commodity that influenced Highlanders, as demonstrated by the remarkable career of Randall MacDonnell, the first earl of Antrim. Notwithstanding his Catholicism, MacDonnell, Scottish by birth but a prominent landholder in the north of Ireland, gained the patronage of the Protestant James I (VI of Scotland) in the early years of the 17th century. MacDonnell transformed himself from a war leader once allied with the Gaelic Irish fighting against the English in Ireland to a 
principal proponent and beneficiary of the Ulster Plantation, James I's effort to transform the north of Ireland into a land peopled by loyal Protestant Britons by imposing a system of English-style towns, villages and cultivated landscapes. ${ }^{21}$

Like the Campbells discussed by Dalglish, MacDonnell transformed his principal residence, the 15th-century Dunluce castle (Fig. 2), into a Renaissance manor house featuring large windows, soaring chimneys, and accompanied by a Mediterranean-inspired loggia and formal gardens in notably optimistic defiance of its exposed position on a basalt outcrop high above the Irish Sea. Signifying his own enthusiastic embrace of newly emerging ideas of both mercantilism and civic society, MacDonnell built a town at Dunluce complete with paved streets and stone houses intended to serve as a profitable entrepôt.

Such activities were paralleled on the other side of the Atlantic at Jamestown, where colonial elites attempted to construct an English town that would not only bestow upon the struggling colony a sense of order and civility, but would bring wealth through the commoditisation and exploitation of natural resources. ${ }^{22}$ MacDonnell's activities could readily be employed as an exemplar of the inexorable crush of proto-capitalist ideologies on the lives of the non-elite. But in reality, MacDonnell and other Ulster Planters were dependent upon the existing population as much as upon the settlers (Catholic as well as Protestant) that he managed to lure from primarily MacDonnell territories in Scotland. Moreover, as aware as MacDonnell was of changing fashions and ideologies, his endeavour to usher in some version of what we might see as capitalist modernity through speculative urban development was fundamentally flawed: his maritime entrepôt and idealised plantation centre had no viable harbour. New ideas and experiments were no match for the imposing cliffs that had long protected the castle from attacks from the sea. ${ }^{23}$

As we look backward in time to elucidate the origins of capitalist modernity, and tease out the evidence for proto-capitalist activity such as that of MacDonnell, it is critical to bear in mind that people in the past could not predict the future. In many instances, they were unsure or unclear about the outcome of their decisions, whereas from our removed perspective we tend to only see the actions and events that appear to lead directly to where we are today. MacDonnell's failed development is a key case in point, as is the story of the larger effort to reform the north of Ireland through the importation of loyal British settlers. 
Long painted as a stark process that imposed capitalist inequality upon a disenfranchised pastoral Gaelic world, archaeological evidence increasingly reveals the haphazard and incomplete nature of this plantation process. Some parts of the north of Ireland, for example the parts of counties Antrim and Down that attracted a critical mass of lowland Scottish settlers, did see major changes in land use and settlement. But even there, the imprint of the past was never erased, with plantation towns depicted in early maps replete with Irish vernacular buildings, and with medieval routeways and land divisions surviving to this day. Elsewhere, the demographics and economic realities made a mockery of plantation precepts. $^{24}$

The efforts to impose plantation on Ireland, inspired by early modern colonial ideologies and practices based in part on the interpretation of classical sources, were occurring at the same time as were the first British efforts to plant colonies in North America. As the effective start point for much North American historical archaeology, the early period of British expansion has been credited with the development and imposition of a fundamentally new way of ordering and understanding the world that has been interpreted as inherently different from earlier periods and marked especially by the interrelationship between capitalism, colonialism, Eurocentrism, and modernity. ${ }^{25}$ This notion of a definable break with the past precipitated by Atlantic expansion is not universally accepted, and is particularly problematic when examined from the perspective of European post-medieval archaeology. For example, archaeological studies of the widespread influence and activities of the Hanseatic trading league, starting in the 14th century, must consider the emphasis upon profit and investment as capitalistic at least in some form. More specifically, Natasha Mehler and Mark Gardiner have also argued that the asymmetrical power relations established by the Hansa in their trading relations with the inhabitants of Iceland and the Faroe Islands in effect created the conditions for the later imposition of colonialism on the islands in the 17 th and 18 th century. ${ }^{26}$

Frans Verhaege notes that, far from being static and unchanging, medieval European society underwent a range of fundamental transformations long before the impacts of Atlantic expansion, including 'the emergence of new urban societies, networks and cultures, and most if not all leading to greater complexity in terms of society and social stratification, economy, and social and cultural behaviour. ${ }^{27}$ In terms of the timing of the emergence of 
capitalist practices within England, one need look no further than the expansion of the wool export trade in the late 14th century, materially marked by the development of commercial buildings such as London's Blackwell Hall, which served as the centre of the English woollen market from the late 14 th through 18 th centuries. $^{28}$ These archaeological insights on medieval capitalistic formulations are strongly influenced by the Annales School, echoing the 1944 words of Marc Bloch: 'capitalism with a capital ' $C$ ', what date shall we assign to its appearance? The twelfth century in Italy?... the eighteenth century, or even the nineteenth?

There as many birth certificates as there are Historians. ${ }^{29}$ The work of Fernand Braudel in particular can be seen as highly influential on post-medieval archaeology, itself traditionally linked much more closely to history as a discipline rather than linked to anthropology, as is the case for North American historical archaeology.

Consideration of the increasingly global nature of exchange relations from the 17th century onwards necessarily leads into a consideration of globalisation; a framework that while seldom explicitly referenced in post-medieval archaeology, nonetheless is core to understandings of material culture, exchange networks, and cultural transformations. As with capitalism, then, post-medieval archaeology has actually contributed much to our understanding the actualities of the processes and ongoing impacts of globalisation, as explored below. However, greater overt engagement with theoretical approaches to both capitalism and globalisation is needed to more fully demonstrate the potential of postmedieval archaeology to contribute significantly to global archaeological discourses.

\section{GLOBALISATION AND POST-MEDIEVAL ARCHAEOLOGY}

Globalisation, like capitalism, cannot be understood as a phenomenon which emerged, fullyformed, during the post-medieval era. Nor can globalisation be viewed simplistically as the imposition of Western-style capitalism on the rest of the world, notwithstanding arguments about the 'Americanization' of the global economy as exemplified by the global penetration of Coca Cola and Ronald Macdonald in the latter half of the twentieth century. ${ }^{30}$ Contemporary approaches to the study of globalisation vary considerably in definition and focus, but tend to emphasise the geographical extent and character of exchange relations and the way those relations fundamentally reshape local practices including labour organisation and social discourse. ${ }^{31}$ At a very basic level, then, globalisation can be 
understood as a process whereby intensified social, economic, and political engagements transcend considerable geographical distances and link together disparate polities to variable extents. Archaeological studies that employ globalisation as a lens specifically seek to understand and characterise the nature of those global and local linkages particularly through their material signatures.

While this article is not the place for a lengthy discourse over the appropriate chronological framework for globalisation, it is worth noting that there is considerable disagreement over when the process began, ranging from perspectives which see it as post-dating 1989 and the fall of the Berlin Wall, or at the other end of the spectrum, as fundamentally rooted in the long distance trade relations developed by early agricultural societies. ${ }^{32}$ Complex political economic relationships have certainly always existed between distinct societies and history cannot be simplistically characterised by an unqualified increase in global interconnectedness over time. By way of example, Moore and Lewis use documentary and archaeological evidence to argue that urban Bronze and Iron Age societies of the Near East participated in many of the same 'international' business practices recognisable today, with regulated markets and roles akin to chief executives and shareholders. While not without its critics, particularly ancient historians, their perspective makes a valuable contribution to contemporary discourse over the origins of globalisation. ${ }^{33}$ For our purposes, we will treat the early modern period, and the increase in global trade relations predicated not only by European expansion but also the expanding reach of and demand for commodities as diverse as Chinese porcelain, Irish linen, and New World tobacco as constitutive of a form of globalisation.

Not surprisingly, North American historical archaeologists studying the 17th and 18th centuries have traditionally been strongly influenced by world systems theory; both as rooted in the work of the Annales School but in particular as articulated by Emmanuel Wallerstein, given the readiness with which his concepts of core and peripheral regions can be applied to address the relationship between European powers and colonial holdings particularly in the early modern Atlantic. ${ }^{34}$ Steven Pendery, for example, has explicitly evoked Wallerstein in addressing the movement of Portuguese ceramics to New England through highlighting Wallerstein's analysis of the role of Lisbon as a centre for the 
transhipment of Eastern goods to the wider European and European-influenced world, and the complex 'commercial relationships between New England, the Portuguese mid-Atlantic archipelagos, the British Isles, and Portugal. ${ }^{35}$ While not explicitly citing Wallerstein as an influence, Marcel Moussette's 2009 article in Post-Medieval Archaeology nonetheless takes as a starting principle the inequal power relations between the European core and peripheral indigenous societies as he considers the impact of European colonial expansion on Native societies in the north-eastern portions of the American continent as being fundamentally shaped by mercantile capitalism: 'At the end of the protohistoric period, it seems that Amerindian societies, despite the relative stability of their cultural systems when in direct or indirect contact with the Basque, Breton and Norman newcomers, had become increasingly involved in the world economy through the capitalist expansion of the Atlantic zone and through the fur trade. As a result, they were probably already affected by changes that presaged the enormous upheavals they would undergo in the 17 th century. ${ }^{36}$

World systems approaches are certainly effective in interpreting the macroscale level of the unequal relations between core and peripheral regions and peoples, but can be critiqued on two levels: first, for downplaying the role and significance of non-Western political economies and cultural expressions (as in Moussette's analysis of the impact of capitalism and colonialism on indigenous societies which does not consider the concomitant impacts of those forces on the European fishers and colonisers), and secondly for a failure to adequately address the richness of the microscale level of engagement. ${ }^{37}$ Here the work of Mary Helms is often evoked, as she has provided an in-depth investigation of the meaning of geographical distance to people around the world, arguing for multiple ways of conceiving differences between the local and the distant. ${ }^{38}$ No matter what form these divisions take, as concentric zones or discrete boundaries, knowledge of lands and people beyond them, either through direct interaction or through the acquisition of objects associated with them, can imbue an individual with special significance, marking them as different from the 'common person' who has never ventured forth among 'the other' ${ }^{39}$ A materially-rich example of such long distance exchange in this manner emerged from a development-driven excavation of features associated with 17th-century households on Narrow Street in Ratcliff, near Limehouse in London, documented to have been primarily 
occupied by the well-to-do families of privateers and sailors. In addition to objects reflective of considerable economic and social standing such as Venetian table glass and decorative tin-enamelled wares from the Mediterranean, domestic assemblages also incorporated a surprising range of non-European ceramics, including Caribbean and Persian wares, seldom, if ever, found on English sites. ${ }^{40}$ This remarkable assemblage also provides a rare opportunity to transcend that boundary between the macro and microscales of analysis so challenging when contemplating globalisation. We actually know the names of many of the mariners who lived in or near Narrow Street, allowing for an informed reimagining of an individual like Captain William Goodson, whose activities included exporting shoes to Barbados and fighting against the Spanish in the Caribbean in the 1650s, acquiring a locally made, Colono-ware type vessel like that recovered from a pit in Narrow Street; or Ratcliff resident William Swanley, who captained the East India fleet in India between 1618-1620. Documents indicate that Swanley exported quantities of Persian spices; perhaps his interest in Persian cuisine led to the acquisition of Persian pottery, such as the soft-paste stoneware tea bowl recovered from the site.

While the authors of the study did not speculate on the precise meaning of these objects for their owners, there are no shortage of fruitful, theoretically-informed approaches that can inform an interpretation of the assemblage. A biographical approach to just one of those objects, the colonoware vessel, would bring together consideration of the original producer of the pot, and its localised meaning --one already freighted with colonial inequities and the material impact of colonial entanglement- with the nature of the interactions that brought the pot into the daily orbit and attention of Goodson. ${ }^{41}$ What value might Goodson have placed on the object and its acquisition? Was it an intentional purchase or merely the retention of a vessel used within Goodson's Caribbean residence, linked to the work of a domestic servant? Why retain the vessel and carry it across the Atlantic? Was it a reminder of place and cuisine, or a symbol of hegemony? Or an unremarkable everyday object of so little value it escaped attention in the packing up of household effects? Precisely how Goodson physically engaged with, and understood, the pot is ultimately unknowable, however, given the recursive relationship between objects and people that is fundamental to understandings of materiality we can assume that Goodson and the members of his households, both in Limehouse and in the Caribbean, would have been impacted in some 
way through engagement with an object that embodied the connection between two geographically and culturally distant places. ${ }^{42}$

A somewhat analogous example comes from the other side of the Atlantic, where archaeologists exploring the traces of the fort built in the first years of the Jamestown colony have unearthed extremely rich deposits of material, often dumped into wells and other features, that speak both to the trauma of the early years of the Virginia colony as well as yielding incomparable insights into the individual engagements of English people with the local world of the Powhatan people. Alongside the heaps of armour and discarded personal items, a unique pot was unearthed that has been attributed to the pipe-maker Robert Cotton. ${ }^{43}$ Made of local clay impressed into a basket, the pot gives the outward appearance of mimicking Powhatan ceramic forms, given its rounded bottom and basket markings. Yet it is an inexact copy in that it is not coil-built as a proper Powhatan pot should have been, and its basket impressions differ from the more common simple stamping found in the region. Cotton's inexpert Powhatan pot suggests a fascination with Powhatan material culture perhaps also implied by Goodson's curated colonoware pot; an interest that because it involved an effort at replication, may reflect a deeper mimetic process than the scientific curiosity displayed by collectors such as John Tradescant the Younger who operated in Virginia in the 1620 s. $^{44}$ The most well-known item collected by Tradescant was the robe or wall hanging known as Powtahan's mantle that continues to be displayed in the Ashmolean museum in Oxford. Such collecting for knowledge, as discussed by Adriana Turpin (building on the ideas of Igor Kopytoff), bestowed a form of status on the holder through the act of acquisition and display. ${ }^{45}$ The value placed on such curiosities and exotica was rooted in their otherness and in the power of possession- rather different than the act of incomplete replication exhibited by Cotton's pot. Whether indicative of a deeper mimetic process or not, the singular vessel found at Jamestown has the power to connect both the extremely microscale- the work and thought processes of a single documented pipe-maker, with macroscale colonial engagements.

The challenge of scale has also been highlighted by Frederic Cooper in his critique of theories of globalisation: 'that global should be contrasted to local, even if the point is to analyse their mutual constitution, only underscores the inadequacy of current analytical tools to analyse anything in between. ${ }^{46}$ Carefully considered and contextualised 
archaeological narratives can bridge that divide through joining together both the very local, including individual engagements with economic and cultural processes and ideologies, with the global and seeing them not as contrasting, but as entangled and interdependent as illustrated by the Cotton pot. A look at two case studies focusing on clay tobacco pipes can further help to illustrate this point through linking the processes of capitalism and globalisation with a closer consideration of individual experiences and identity transformations.

In two different parts of the world, in the middle of the seventeenth century, local craftspeople began producing clay tobacco pipes out of terracotta clays, in part motivated by a desire for profit through producing a cheaper alternative to imported English and Dutch ware. These two locales were Carrickfergus, an English garrison and plantation town in county Antrim in the north of Ireland, and the colonial Chesapeake, in eastern North America. These locally made terracotta Chesapeake pipes have long intrigued scholars, as discussed by Kathryn Sikes. ${ }^{47}$ Clearly developed from local Algonquian forms, the pipes sport a range of decorative motifs that have alternatively been interpreted as Native, African, and European. Turning on the argument on its head, Sikes considers how this object, and its ambiguous designs, could both knit together individuals of different ethnic backgrounds in a common activity: smoking, yet at the same time the different ways in which the star motif in particular (fig. 3) could be understood according to cultural background serves as a metaphor for the limits of hybridisation. Chesapeake pipes, then, were not only tobacco delivery devices whose use was determined by global economic exchange, they were active agents in the constructing of both new social and cultural relations yet fundamental to the maintenance of traditions. Chesapeake pipemakers were concomitantly displaying capitalistic motivations while continuing a pre-capitalist tradition, and participating in the cultural transformations within a society in ways far more complex than can ever be explained through simple acculturation frameworks or expectations of the totalising nature of capitalistic formulations.

By contrast, whoever produced the small and unique assemblage of undecorated terracotta smoking pipes found in the excavation of one mid-17th-century site in Carrickfergus evidently did not succeed in answering any particular cultural or even economic need. Well connected to the port of Chester, goods came into Carrickfergus regularly and cheaply. 
Found nowhere else in Carrickfergus or beyond, it seems these pipes were merely an experiment- an effort by a local potter to subvert the market and answer a local need, but an experiment that seemingly failed. In the Chesapeake, the locally-made pipes clearly served a need beyond that of a desire for a cheap pipe. ${ }^{48}$ In Carrickfergus, the red clay pipes apparently served no particular social need that outweighed the utility of imported white ball clay tobacco pipes. That such local contingencies shaped demand and impacted upon the circulation and consumption of goods is perhaps unsurprising, but nevertheless such microscale examples serve as an important corrective to overly prescriptive models of consumption activity.

The multivalency of objects is well-illustrated through post-medieval archaeology. As illustrated by the cabinets of curiosity discussed above, the meanings of objects can be transformed through geographic as well as cultural distance. Ordinary items in one land become luxury items in another, as prosaically exemplified by the appearance of ceramic stove tiles in England and pantile roofs in coastal Norfolk. Tiled stoves were developed in transalpine Europe by the 14th century, and by the 16th century they were commonly used as heating devices in homes throughout Scandinavia and the Alps. Documentary and archaeological evidence reveals that when these objects crossed the channel they shifted from being ordinary items available to nearly all levels of society to an exclusive luxury commissioned by wealthy individuals; many of whom had witnessed their use when traveling on the continent. ${ }^{49}$ While tiled stoves never became widely adopted in England, given the relative scarcity of wood for fuel, roofing pantiles followed a different trajectory. First a luxury imported from the Netherlands and only used by elites in the 16th century, pantiles then became one of many roofing options available to a fairly broad subset of Norfolk society as trade increased in the 17 th century. Finally, the pantile transitioned into a local staple as Norfolk manufacturers began making pantiles which were then used by the majority of regional households in the 18th century. ${ }^{50}$

In contrast, the excavation of a late 17 th- and early 18th-century tin-glazed earthenware kiln in Lambeth, London demonstrates a very different approach to the consumption and exchange of goods. Despite the fact that the owners and primary operators of this factory were English citizens, they constructed the kiln in a style more popular in continental Europe than on the British Isles and almost exclusively produced tin-glazed earthenware in the 
same forms and decorations typical of ceramics produced in the city of Delft at the time. ${ }^{51}$ The owners of this pottery chose to produce these highly-commodified objects in order to tap into the same network of distributors and marketers who acquired tin-glazed ceramics from Delft and sold them in London. It has long been recognised that the popularity of this type of ceramic amongst individuals at all levels of English society relates to how its forms and decorations imitated those of imported Chinese porcelain. ${ }^{52}$ This phenomenon was of course not confined to ceramics but affected many different types of consumer goods, as manufacturers of new global luxuries co-opted the distribution networks developed by the importers of exotic goods from around the world. Thus, the origins of globalisation as reflective of global geographic space must be understood as occurring in the places in between localities, in the social and economic networks of manufacturers, merchants, and investors from around the world which organized and structured the translocation of physical goods in the post-medieval period.

The increasing availability and consumption of items deemed to be luxuries was accompanied by considerable cultural anxiety. ${ }^{53}$ Beginning in the mid-17th century, writers and pamphleteers in northwest Europe published a series of debates about the nature and morality of luxury goods. Initially judging the consumption of luxury items as excessive and associated with the elite and politically powerful, rhetoric shifted over the course of the late 17th and 18th centuries to a perspective wherein the consumption of luxuries signalled taste and sophistication, and importantly as essential to the economic health of a society. ${ }^{54}$ Building on Marx's analysis of conspicuous consumption in the 18th and 19th centuries, Pierre Bourdieu's classic work Distinction explores the role played by consumption in the maintenance of elite power structures; a perspective that continues to inform and influence understandings of the role played by commodities in post-medieval Europe. ${ }^{55}$ However, the closer alignment of post-medieval archaeology with history rather than with anthropology has meant that seminal anthropological studies such as Douglas and Isherwood's 1979 The World of Goods, which brought together economic and cultural perspectives on consumption, have had less of an influence than the work of economic historians such as McKendrick and Jan de Vries. De Vries explicitly contrasts old luxuries (produced exclusively for elites) with new luxuries which worked to obscure their biographies: each object was produced to be as similar as possible to others of the same 'type' and were exchanged 
through a series of middlemen so that consumers were presented with a range of potential options according to their buying power. ${ }^{56}$ Old luxuries maintained their exclusivity by explicitly referring to the processes by which they were manufactured or exchanged, either by being made by particularly skilled craftsmen or artists from rare materials and/or by originating beyond a geographically meaningful distance. Put another way, old luxuries could be valuable because they were obtained from a geographically distant place, new luxuries were valuable because it did not matter where they were produced.

While this distinction between old and new luxuries does not preclude the role consumerism played in the reification of social hierarchies as explored by Marx and Bourdieu, de Vries' reading of the active engagement of all levels of society arguably provides space for the inclusion of the agentive approaches that currently characterise British material culture scholarship. This scholarship draws heavily upon anthropological frameworks to focus on the active ability of individuals to employ objects in identitymaking. ${ }^{57}$ The work of material culture scholars such as Daniel Miller strongly influences the new research on contemporary archaeology which has now found a place on the pages of Post-Medieval Archaeology, ${ }^{58}$ but has arguably been slow to penetrate the study of earlier periods. An important exception is Ross Wilson's 2008 discussion of 18th-century English consumerism, where he draws inspiration from Bruno LaTour in sharply critiquing historical approaches to consumerism than focus only on objects as commodities rather than active 'participants in the society which utilizes them. ${ }^{59}$

The movement of objects in the early modern period is only one part of the nascent process of globalisation. People, plants, animals, and disease vectors also circulated irrespective of national borders, in a process that differed significantly in scale from earlier patterns of biological exchange. ${ }^{60}$ Rather than slowly transitioning between exotically sourced luxury and locally produced staple, as has been observed by the movement of flora in the ancient world, ${ }^{61}$ many species associated with the Colombian Exchange, like tobacco, sugar, and Carolina rice, became cash crops, products which were widely available to both social elites and non-elites despite being transported over significant geographic distances. ${ }^{62}$ The exploitation of these new cash crops was dependent upon a new scale of human 
exploitation- the forced movement and enslavement of millions of people from the African continent to the Americas. While archaeologies of the African diaspora constitute a vibrant subfield of historical archaeology, it is fair to say that post-medieval archaeology has yet to demonstrate the potential of exploring the impacts of the Atlantic slave trade on the home societies of the slave traders. ${ }^{63}$ Despite the wholesale entanglement of British ports and cities in the exchange of people and things, as well as the historic existence of African and African-descendant communities within the United Kingdom, articles within Post-Medieval Archaeology which reference slavery are exceptionally rare, and are either focused on geographic locations outside of Europe (eg. the Caribbean and Bermuda), or address the abolitionist movement. ${ }^{64}$ One recent and welcome exception is a study by Jane Webster which highlights the development of a previously unremarked English proslavery material culture, exemplified by the production of ceramics commemorating Liverpool-based slave ships. $^{65}$

Ships crossing the Atlantic not only carried intentional human cargo and exchange goods, but also facilitated a host of intended and unintended biological and entomological exchanges that must also be understand as central to processes and consequences of globalisation, rather than merely a correlate. In other words, as argued by Stephen Mrozowski, 'the environment must be taken into account as both context and active agent in the historical trajectories of colonization, industrialisation and urbanization as global processes. ${ }^{66}$ Notwithstanding the historic strength of environmental approaches in British archaeology more generally, the application of environmental analyses to later historical archaeology have been more fully explored in North America; for example, the extensive landscape changes in the Chesapeake precipitated by the introduction of European domestic livestock, and the examination of the impact of ballast dumping in the Avalon Peninsula of Newfoundland, which resulted in the introduction of 'more introduced Carabidae, or ground beetles, than any other area of North America. ${ }^{67}$

While fewer in number, there are good examples of the potential for environmental analyses in British post-medieval archaeology, particularly in relation to the impact of New World species into Europe. Brooklynne 'Tyr' Fothergill has recently examined the cultural and faunal impacts of the introduction of the American turkey into Europe, ${ }^{68}$ while singular 
discoveries of exotic animals, such as the jawbone from a South American capuchin monkey uncovered from a 17th-century deposit at Brooks Wharf, London, also speak to the intentional biological exchanges facilitated by scientific curiosity of, as described by Alison Games, 'English cosmopolitans. ${ }^{69}$ Similarly, archaeological and documentary examinations of historic garden landscapes, particular from the 18th century, have illuminated the intentional, scientific exchange of flora and fauna, as illustrated by Clare Hickman's examination of the Earl's Court landscape garden of the scientist and anatomist John Hunter. $^{70}$

Returning to the significance of scale, post-medieval archaeologists have productively examined the timing and dispersal of people, flora, fauna and objects across the world and their meanings within localities as well as in individual households. But if we wish to more fully address the character of the broader processes of globalisation itself, it then becomes necessary to consider the consumption practices of geographically-distant places in comparative perspective, to tease out the complex web of interrelationships. A case in point of the increasingly global nature of interdependency is provided by Alasdair Brooks, who has examined the impact of the American Civil War on the types of pottery consumed in Australia. On the surface unconnected, a macroscale comparison of the mid-19th-century export of Staffordshire wares, rooted in both the archaeological and historical records, reveals that when trade to the US was curtailed by warfare, the plain white ceramics preferred by the American market were shipped to the more captive market of Australia, notwithstanding a greater local preference for decorated wares. ${ }^{71}$ Additionally, comparisons between the ceramic assemblages of middling rural households in the western Scottish lowlands and Virginia suggest that while individuals in both areas came to primarily consume highly-commodified Staffordshire-made industrial ceramics over the course of the 18th century, the timing and the incentives for this change in consumer behaviour differed significantly based on local historical contingencies. ${ }^{72}$

The individuals who participated in these exchanges were not necessarily attempting to forge (or dismantle) a globalised world that lay in a future they could not predict. As Cooper points out, 'The problem with making integration the standard - and measuring everything else as lack, failure, or distortion - is that one fails to ask what is actually happening. ${ }^{73}$ 
Different localities experienced increasing global entanglements and interdependence in variable ways, each with their own unique relationships with supra-territorial networks. Archaeology provides a means to explore these variations and to tackle the global scale through interrogating the micro scale. Even highly-commodified global luxuries must be understood in their relation to their local context in order to interpret the range of meanings with which they were imbued. ${ }^{74}$ Globalisation, as it is defined here, is an important process in the creation of the modern world that is fundamentally entwined with the forces of capitalism and colonialism. However, if not approached from a multi-scalar perspective, we run the risk of assigning these intertwined forces a coherence and uniformity they never possessed.

\section{CONCLUSION}

In the first yearly publication of the Society for Post-Medieval Archaeology, David Crossley, then lecturer in economic history at the University of Sheffield, contributed an article describing his excavation of a glass furnace operated in the early 16th-century in Staffordshire. While not explicitly addressing capitalism, Crossley pondered the potential profits that the glasshouse may have accrued through reference to documentary sources from contemporary glasshouses. Crossley calculated that, after balancing the expenditure costs with the possible sale price of the product, the owner of the glasshouse could have made a profit every year. ${ }^{75}$ Crossley's conclusion is entirely logical if we view capitalism as in an immutable system wherein the acceptance of some of its aspects, like paid wages, necessitates embracing the worldview as a whole. However, in the fifty years since Crossley's study was published, we have become increasingly aware of the spotty and incomplete nature of the capitalist transformation. In the specific case of the Staffordshire glassworks, social relationships governed credit and debt relationships which would have had a considerable impact upon the generation, and indeed meaning, of profit. ${ }^{76}$

Capitalist systems are not immutable, as demonstrated by both the archaeological examples above and the work of social theorists. To note the differences that can exist between equally capitalist systems, one simply has to observe the difference between the Adam Smith's denunciation of labour that does not "[realize] itself in some particular subject or vendible commodity, which lasts for some time at least after that labour is past" as 
unproductive, ${ }^{77}$ and the reality of present day corporate capitalism wherein "the factory and the shop ... are increasingly experienced by virtue of their erasure. ${ }^{\prime 78}$ In fact, the industrial capitalism touted by Adam Smith and critiqued by Karl Marx, marked by large numbers of fairly small firms funded by small groups of wealthy investors wherein the production of objects - Smith's 'vendible commodities'- was the primary goal, is in part an adaptation of capitalist ideologies to the early modern English landholding systems. Beginning around the 16th century, members of the landowning gentry were encouraged to construct workshops on their rural estates and hire non-local artisans to get the most value from their lands. ${ }^{79}$ Thus, the differences between the British industrial capitalism of the 19th century and American corporate capitalism of the late 20th century can be traced back to historical developments in medieval and early modern England. By exploring these connections to a deeper past, archaeologists have made notable advances in the study of capitalism and global networks of material exchange.

From its original narrow conceptualisation of the study of post-medieval Britain and Europe between c. 1500 to the onset of industrialisation, post-medieval archaeology, as reflected on the pages of Post-Medieval Archaeology, not only looks to medieval roots but now also embraces the study of the contemporary world, as further explored in this volume by Laura McAtackney and Sefryn Penrose. ${ }^{80}$ Such studies connect past and present, as exemplified by Paul Graves-Brown's exploration of how the emergence of increasingly fast communications systems and the containerization of shipping in the mid-20th century precipitated a significant expansion in supra-territorial interactions. ${ }^{81}$ This development, however, was dependent upon the creation of markets for highly-commodified, mass produced goods which began in the late 17 th century.

Finally, the current expansion of post-medieval archaeology/ historical archaeology around the globe promises to further complicate and challenge traditional Western understandings of the emergence of modernity and its material signatures. Contemporary research on the archaeologies of the last five hundred years in South America, Africa, the Middle East, India, and East Asia is providing an invaluable complication of understandings of globalisation, particularly when associated with post-colonial critiques. Archaeological practice in these regions requires a forthright engagement with the legacies of European expansion, strengthening and deepening the contemporary relevance of historical archaeology and 
serving as an exemplar for the transformation of practice in the historic cores of the discipline. ${ }^{82}$ Any consideration of capitalism and globalisation that did not consider the present would be perpetuating an artificial separation between past and present, as if the past was complete and the present fundamentally different. In reality, we continue to struggle with the same issues of inequality, incompleteness, and an inability to predict the future that exercised people in the past. The increasing diversity and vibrancy of global archaeological practice, embedded in an awareness of the ongoing legacies of early modern colonialism, promises to not only enhance our understandings of capitalism and globalisation, but more importantly to ensure the social relevancy of archaeology.

\section{BIBLIOGRAPHY}

Appadurai, A. (ed.) 1986, The Social Life of Things: Commodities in Cultural Perspective, Cambridge: Cambridge University Press.

Armitage, P. 1981, 'Jawbone of a South American monkey from Brooks Wharf, London.' London Archaeol. 4:10, 262-70.

Atkinson, D. \& Oswald, A. 1972 'A Brief Guide for the Identification of Dutch Clay Tobacco Pipes Found in England.' Post-Medieval Archaeol. 6, 175-182

Bateman, N. 2004, 'From Rags to Riches: Blackwell Hall and the Wool Cloth Trade c. 14501790.' Post-Medieval Archaeol. 38:1, 1-15.

Barker, D. 1999, 'The Ceramic Revolution 1650-1850,' in Egan \& Michael 1999, 226-234.

Barker, D. \& Horton, W. 1999, 'The development of the Coalport Chinaworks: an analysis of the finds.' Post-Medieval Archaeol 33:1, 3-93.

Belcher, J. \& Jarrett, M. 1971, 'Stem-Bore Diameters of English Clay Pipes: Some Northern Evidence.' Post-Medieval Archaeol. 5, 191-193.

Belford, P. 2010, 'Five centuries of iron working: excavations at Wednesbury Forge', PostMedieval Archaeol. 44, 1-53. 
Berg, M. 2007, Luxury and Pleasure in Eighteenth-Century Britain, Oxford: Oxford University Press.

Bloch, M. 1953, The Historian's Craft. Manchester: Manchester University Press.

Bloice, B. 1971, 'Norfolk House, Lambeth: Excavations at a Delftware Kiln Site, 1968', PostMedieval Archaeol. 6, 99-159.

Boivin, N., Fuller, D.Q. \& Crowther, A. 2012, 'Old World globalization and the Columbian exchange: comparison and contrast', World Archaeol. 44, 452-469.

Bowen, J. 1994, 'A comparative analysis of the New England and Chesapeake herding systems,' in Shackel \& Little 1994, 155-167.

Breen, C. 2012, 'Randal MacDonnell and early seventeenth-century settlement in northeast Ulster, 1603-30', in Ó Siochrú \& Ó Ciardha 2012, 143-147.

Brooks, A. 2009, 'The View from Afar: International Perspectives on the Analysis of post1750 Ceramics in Britain and Ireland,' Horning \& Palmer 2009, 287-300.

Brooks, A. \& Rodriguez Y. A. 2012, 'A Venezuelan household clearage assemblage of 19thcentury British ceramics in an international perspective', Post-Medieval Archaeol. 46, 70-88.

Brown, M. 1999, The Practice of American Historical Archaeology in Egan \& Michael 1999, 23-32.

Buchli V. (ed.) 2001, The Material Culture Reader, New York: Berg.

Butler, L.A.S. 1967, 'Editorial,' Post-Medieval Archaeol. 1, 1-2.

Cipolla, C. \& Hayes, K.H. (eds) 2015 Rethinking Colonialism: Comparative Archaeological Approaches Gainesville: University of Florida Press.

Chandra, N. 2007, Bound Together: How Traders, Preachers, Adventurers, and Warriors Shaped Globalization, New Haven: Yale University Press.

Comaroff, J. \& Comaroff, J. 2005, 'Millennial Capitalism and the Culture of Neoliberalism,' in Edelman \& Haugerud 2005, 177-188. 
Cooper, F. 2005, Colonialism in Question: Theory, Knowledge, History, Berkeley: University of California Press.

Cooper, F. 2001, 'What is the concept of globalization good for? An African historian's perspective', African Affairs 100, 189-213.

Cornell, P. 2015, 'Colonial Encounters, Time, and Social Innovation,' in Cipolla \& Hayes 2015, 99-120.

Crewe, V. 2012, Ancient Luxury and Modern Filth: New Insights into 19th-Century Life at Sheffield Manor Lodge, Post-Medieval Archaeol. 46:2, 333-366.

Crossley, D. 1967, 'Glassmaking in Bagot's Park, Staffordshire, in the Sixteenth Century', Post-Medieval Archaeol. 1, 44-83.

Crawford, I.A. 1969, 'The Divide between Medieval and Post-Medieval in Scotland,' PostMedieval Archaeol. 1, 84-89.

Croucher, S. \& Weiss, L. 2011, 'The Archaeology of Capitalism in Colonial Contexts, an Introduction: provincializing Historical Archaeology' in Croucher \& Weiss 2011, 1-38.

Croucher, S. \& Weiss, L. (eds) 2011, The Archaeology of Capitalism in Colonial Contexts: Postcolonial Historical Archaeologies, New York: Springer.

Dalglish, C. 2005, 'An age of transition? Castles and the Scottish Highland estate in the 16th and 17th centuries.' Post-Medieval Archaeol 39:2, 243-266.

Dawson, D. \& Kent, O. 2008, 'The development of the Bottle Kiln in Pottery manufacture in Britain,' Post-Medieval Archaeol. 42:1, 201-266.

De Munck, B. \& Lyna, D. (eds.) 2015, Concepts of Value in European Material Culture 15001900, Surrey: Ashgate.

De Vries, J. 2008, The Industrious Revolution: Consumer Behavior and the Household Economy, 1650 to the Present, Cambridge: Cambridge University Press.

Gaimster, D. \& Stamper P. (eds) 1997, The Age of Transition: the Archaeology of English Culture 1400-1600 Oxford: Oxbow. 
Deetz, J. 1977, In Small Things Forgotten: an Archaeology of Early American Life, New York: Anchor Books.

Diamond, J. 1999, Guns, Germs and Steel: the Fates of Human Societies, New York: Norton.

Dixon, J. 2011, 'Is the present day post-medieval?' Post-Medieval Archaeol. 45:2, 313-321.

Edelman, M. \& Haugerud, A. 2005, The Anthropology of Development and Globalization: From Classical Political Economy to Contemporary Neoliberalism, Oxford: Blackwell.

Egan, G. \& Michael, R.L.(eds) 1999, Old and New Worlds, Oxford: Oxbow.

Ferris, N., R. Harrison, M.V. Wilcox (eds). 2014, Rethinking Colonial Pasts through Archaeology, Oxford: Oxford University Press.

Flatman, J. 2003, 'Cultural biographies, cognitive landscapes and dirty old bits of boat: 'theory' in maritime archaeology', International Journal of Nautical Archaeology 32:2, 143157.

Friedman, T. 1999, The Lexus and the Olive Tree: Understanding Globalization. New York: Farrar, Strauss and Giroux.

Frazer, B. 1999, 'Common recollections: Resisting enclosure "by agreement" in seventeenthcentury England.' Intl. Journ. Hist. Archaeol. 3:2, 75-99.

Funari, F. 1999, 'Historical Archaeology from a World Perspective,' in Funari, Hall \& Jones 1999, 37-66.

Funari, P., Hall, M. \& Jones, S. (eds) 1999, Historical Archaeology: back from the Edge, London: Routledge.

Gaimster, D. 1986, 'Preliminary observations on the post-medieval pottery from the AlterMarkt site, Duisburg, West Germany,' Post-Medieval Archaeol 20:1, 19-30.

Gaimster, D. et al. 1990, 'The continental stove-tile fragments from St Mary Graces, London, in their British and European context', Post-Medieval Archaeol. 24, 1-49. 
Games, A. 2008, The Web of Empire: English Cosmopolitans in Age of Expansion, 1560-1660, Oxford: Oxford University Press.

Games, A. 2006, 'Beyond the Atlantic: English Globetrotters and Transoceanic Connections,' William Mary Q. 63:4, 675-692.

Gosden, C. \& Marshall, Y. 1999, 'The Cultural Biography of Objects,' World Archaeology 31:2, 169-178.

Green, A. \& Leech, R. (eds) 2006, Cities in the World Society for Post Medieval Archaeology Monograph Series 3, Leeds: Maney.

Hall, M. \& Silliman, S. (eds) 2006, Historical Archaeology, Oxford, Blackwell.

Hatfield, A.L. 2004, Atlantic Virginia: Intercolonial relations in the seventeenth century, Philadelphia: University of Pennsylvania Press.

Hatfield, A.L. 2003, 'Spanish Colonization Literature, Powhatan Geographies, and English Perceptions of Tsenacommacah/Virginia,' Journ. Southern Hist. 49:2, 245-282.

Helms, M. 1988, Ulysses' Sail: An Ethnographic Odyssey of Power, Knowledge, and Geographical Distance, Princeton: Princeton University Press.

Hodder, I. 2012, Entangled: an archaeology of the relations between humans and things. Wiley-Blackwell, Oxford.

Horning, A. 2016, 'Transatlantic currents: Exploring the past, present and future of global historical archaeology.' Hist. Archaeol. 50:3.

Horning, A. 2013, Ireland in the Virginian Sea: Colonialism in the British Atlantic, Chapel Hill: University of North Carolina Press.

Horning, A. 2012a, Carrickfergus Excavations 1991-1995: The Clay Pipe Report: Stem Bore Analysis. Unpublished report submitted to the Northern Ireland Environment Agency, Belfast.

Horning, A. 2012b, Research design: limited test investigation of historic structures at FC 769 Arichonan, Knapdale. Unpublished manuscript, submitted to Forestry Commission Scotland. 
Horning, A. 2006a, 'Archaeology and the Construction of America's Jamestown,' PostMedieval Archaeol. 40: 1, 1-27.

Horning, A. 2006b, 'English Towns on the Periphery: Seventeenth-Century Town Development in Ulster and the Chesapeake,' in Green \& Leech 2006, 61-82.

Horning, A. \& Palmer, M. (eds) 2009, In Crossing Paths or Sharing Tracks: Future Directions in the Archaeological Study of Post-1550 Britain and Ireland, Woodbridge: Boydell and Brewer.

Hoskins, J. 1998, Biographical Objects, London: Routledge.

James, H. 2003, Medieval and later Landscape and Settlement in Mid-Argyll and Knapdale. GUARD Project Report 1416, 1446 \& 1447, Unpublished mss, GUARD, University of Glasgow.

Johnson, M. 2006, 'The Tide Reversed: Prospects and Potentials for a Postcolonial Archaeology of Europe,' in Hall \& Silliman 2006, 313-331.

Johnson, M. 1999, 'The New Post-Medieval Archaeology,' in Old and New Worlds G. Egan and R.L. Michael, editors, pp. 17-22. Oxford: Oxbow.

Johnson, M. 1996, An Archaeology of Capitalism, Oxford: Blackwell.

Killock, D. et al. 2005, 'Pottery as plunder: a 17th-century maritime site in Limehouse, London', Post-Medieval Archaeol. 39, 1-91.

Kopytoff, I. 1986, 'The Cultural Biography of Things: Commoditization as Process,' in Appadurai 1986, 64-91.

Leone, M. 2005, The Archaeology of Liberty in an American Capital, Berkely: University of California Press.

Leone, M. \& Knauf, J. 2015, Historical Archaeologies of Capitalism, New York: Springer.

Lucas, G. 2006, An Archaeology of Colonial identity: Power and Culture in the Dewars Valley, South Africa, New York: Springer. 
Lucas, R. 1998, 'Dutch pantiles in the county of Norfolk: architecture and international trade in the 17th and 18th centuries', Post-Medieval Archaeol. 32, 75-94.

McGhee, F. 2007, 'Maritime archaeology and the African Diaspora,' in Ogundiran \& Falola 2007, 384-394. Akinwumi Ogundiran and Toyin Falola (eds.) Archaeology of Atlantic Africa. 384-394. Bloomington: Indiana University Press

McGhee, Fred 1998, 'Toward a postcolonial, nautical archaeology' Assemblage 3. http://www.assemblage.group.shef.ac.uk/3/3mcghee.htm

McFarlane, H 2004, Arichonan: A Highland Clearance Recorded, Indiana: Authorhouse.

Macgregor, A. 2007, Curiosity and Enlightenment: collectors and collections from the sixteenth to the nineteenth century, New Haven: Yale University Press.

Matthews, C. 2010, The Archaeology of American Capitalism, Gainseville: University of Florida Press.

Mehler, N. \& Gardiner, M. 2013, 'On the Verge of Colonialism: English and Hanseatic Trade in the North Atlantic Islands.' In Pope \& Lewis 2013, 1-13.

Miller, D. 2010, Stuff, Cambridge: Polity Press.

Miller, D. 2005, Materiality, Durham: Durham University Press.

Miller, D. 1987, Material Culture and Mass Consumption, Oxford: Blackwell.

Mitchell, A. 1881, The Past in the Present: What is Civilization? New York: Harper.

Mizoguchi, K. 2010, 'The Colonial Experience of the Uncolonized and the Colonized,' Handbook of Postcolonial Archaeology, Jane Lydon and Uzma Rizvi, editors, pp. 81-91. Springer, New York.

Moore, K. \& Lewis, D. 2009, The Origins of Globalization, New York: Routledge.

Morley, N. 2011, The Origins of Globalization (review). Enterprise and Society 12:1, 233-235.

Moshenska, G. 2014, The Archaeology of (flash) Memory. Post-Med. Arch. 48:1, 255-259. 
Mrozowski, S. 2014, Imagining an Archaeology of the Future: Capitalism and Colonialism Past and Present, International Journ. Hist. Archaeol. 18, 340-360.

Mrozowski, S. 1999, Colonization and the Commodification of Nature. International Journal of Historical Archaeology 3: 3, 153-66.

Muldrew, C. 1993, 'Interpreting the market: the ethics of credit and community relations in early modern England', Soc. History 18, 163-83.

Newman, R. 2005, 'Farmers and Fields: Developing a Research Agenda for Post-Medieval Agrarian Society and Landscape.' Post-Medieval Archaeol. 39: 2, 205-214.

Nordin, J. 2013, 'The Centre of the World: The material construction of Eurocentric domination and hybridity in a Scandinavian 17th-century context,' Journ. Material Cult. 18:2, 189-209.

Nordin, J. 2012,' Embodied Colonialism: the Cultural Meaning of Silver in a Swedish colonial context in the Seventeenth Century,' Post-Medieval Archaeol. 46:1, 143-165.

Ohlsen, B. 2010, In Defense of Things: Archaeology and the Ontology of Objects, New York, Altamira.

O'Keeffe, J. 2008, The Archaeology of the Later Historical Cultural Landscape in Northern Ireland: Developing Historic Landscape Investigation for the Management of the Archaeological Resource: A Case Study of the Ards, County Down. University of Ulster PhD thesis.

Orser C. 2010, Twenty-first century historical archaeology, Journ. Archaeol. Res. 18, 111-150.

Orser, C. 1996, Historical Archaeology of the Modern World, New York: Springer.

M. Ó Siochrú, M. \& Ó Ciardha, E. (eds) 2012, The Plantation of Ulster: ideology and practice, Manchester University Press: Manchester.

Osterhammel, J. \& Petersson, N.P. 2005, Globalization: A Short History, Princeton: Princeton University Press. 
Oswald, A. 1969, 'Marked Clay Pipes from Plymouth, Devon,' Post-Medieval Archaeol. 3:1, 122-142.

Pope, P. \& Lewis-Simpson, S. (eds) 2013, Exploring Atlantic Transitions Woodbridge: Boydell \& Brewer.

Royal Commission on the Ancient and Historic Monuments of Scotland 1992 Argyll: An Inventory of the Monuments Vol 7 Mid-Argyll and Cowall Medieval and Later Monuments, Edinburgh: HMSO.

Schmidt, P. \& Mrozowski, S. (ed). 2013, The Death of Prehistory, Oxford: Oxford University Press.

Schmidt, P. \& Walz, J. 2007, Silences and Mentions in History Making, Hist. Archaeol. 41:4, 129-146.

Scholte, J. 2000, Globalization: A Critical Introduction, New York: St. Martin's Press.

Schweickart, E. 2014, 'Ideologies of consumption: colonialism and the commodification of goods in 18th-century Virginian and Lowland Scottish rural households', Post-Medieval Archaeol. 48, 398-411.

Shackel, P. \& B. Little (eds) 1994, Historical Archaeology of the Chesapeake, Washington DC: Smithsonian Institution.

Sikes, K. 2008, Stars as Social Space? Contextualising seventeenth-century Chesapeake pipes. Post-Medieval Archaeology 42: 1, 75-103.

Smith, A. 2005, Of the accumulation of capital, or of productive and unproductive labor, in Edelman \& Haugerud 2005, 87-90.

Steger, M.B. (ed.) 2010, The Greatest Hits: A Global Studies Reader, Oxford: Oxford University Press.

Steger, M.B. 2013, Globalization: A Very Short Introduction, Oxford: Oxford University Press. 
Straube, B. 2013, 'The Geoff Egan Memorial Lecture 2012: Surprises from the Soil Archaeological Discoveries from England's First Successful Transatlantic Colony at Jamestown.' Post-Medieval Archaeol. 47:2, 263-280.

Svizzero, S. \& Tisdell, C. 2014, 'Inequality and wealth creation in ancient history: Malthus' theory reconsidered,' Interdiscip. App. Econ. Sociol. 7, 222-239.

Tait, H. \& Cherry, J. 1978, 'Excavations at Longton Porcelain Factory, Part 1,' Post-Medieval Archaeology 12, 1-29.

Tarlow, S. 2007, The Archaeology of Improvement in Britain, 1750-1850, Camridge: Cambridge University Press.

Taussig, M. 1993. Mimesis and Alterity: A Particular History of the Senses. New York, NY: Routledge.

Turpin, A. 2015, The value of a collection; collecting practices in early modern Europe, in Concepts of value in European material culture 1500-1900, Bert de Munck and Dries Lyna, editors, pp. 255-284. Farnham: Ashgate.

Tracey, R. 2015, 'Nodes and modes of identity in early modern Ireland: material culture and cultural entanglements in 17th-century Carrickfergus,' Glasgow: European Association of Archaeologists Conference paper.

Verhaeghe, F. 1997, 'The Archaeology of Transition: a Continental View,' in Gaimster \& Stamper 1997, 25-44.

Watney, B. 1993, 'Excavations at the Longton Porcelain Manufactory, Part III: the porcelain and other ceramic finds,' Post-Medieval archaeology 27, 57-109.

Wilkie, L. \& Bartoy, K. 2000, 'A Critical Archaeology Revisited,' Current Anthro. 41:5, 747777.

Wilson, R.J. 2008, 'The Mystical Character of Commodities': the Consumer Society in 18thCentury England, Post-Medieval Arch. 42:1, 144-156.

Wrathmell, S. 1980, 'Village depopulation in the 17th and 18th centuries: Examples from Northumberland,' Post-Medieval Archaeology 14, 113-126. 
Wurst, L. 1999, Internalizing class in historical archaeology, Hist. Archaeol. 33:1, 7-21

Young, R. \& Fazeli, H. 2013, Women and Class in Landlord Villages of the Tehran plain, Iran.

Hist. Archaeol. 47:2, 76-98.

\section{ACKNOWLEDGMENTS}

We are grateful to Alasdair Brooks and the editorial team of Post-Medieval Archaeology for approaching us to write this article together, and especially for the helpful comments of the anonymous reviewers in strengthening the final article.

\section{LIST OF FIGURES}

Figure 1: Remains of the cleared township of Arichonan, Knapdale (A. Horning)

Figure 2: Dunluce Castle, Co. Antrim (A. Horning)

Figure 3: Locally-made Chesapeake pipe with star motif (A. Horning)

\footnotetext{
1 Johnson 1999; Tarlow 2007, 7-9

2 Eg. Wurst 1999. See Leone and Kaupf 2015; also Leone 2005 and Matthews 2010.

${ }^{3}$ Eg. Gaimster 1986 cites Marc Bloch but does not directly discuss capitalism

${ }^{4}$ Butler 1967, 1-2.

${ }^{5}$ Little remains of Wedgwood's Etruria factory, but following an extensive campaign by the Art Fund the archives of his industry and the ceramic collections were recently purchased and protected from threatened dispersal. The only survival of the Etruria factory is one of the two roundhouses which once flanked the symmetrical façade of the structure. The collections themselves are now on public display as of July 2015. See http://www.savewedgwood.org/ ; Tait and Cherry 1978; Barker and Horton 1999; Brooks and Rodriquez 2012, Dawson and Kent 2008, Watney 1993.

${ }^{6}$ Eg. Atkinson and Oswald 1972, Belcher and Jarret 1971.

${ }^{7}$ Oswald 1969, 126.

8 Johnson 2006, 318.

${ }^{9}$ The traditional North American definition of historical archaeology as post-dating the Columbian voyages is given by James Deetz 1997, 5, as 'the archaeology of the spread of European culture throughout the world since the fifteenth century and its impact on indigenous peoples'.

${ }^{10}$ From a northern European perspective, such studies include work by Jonas Nordin 2012 examining the impact of Swedish colonial engagements on the homeland. Increasingly, studies of Spanish colonialism in the New World are also addressing the influence of indigenous practices on colonial society, for example Per Cornell's 2015 consideration of the formative impact of the Aztec city of Tenochtitlan on the subsequent layout of Spanish American colonial towns. In British colonial North America, another example would be the recognition that a Powhatan cultural geography in effect determined the extent of Virginia colonial settlement for a century. See Hatfield 2003, 2004 and discussion in Horning 2013, 25-36, 159.

${ }^{11}$ For a critical consideration of the Improvement ethic, see Tarlow 2007.

${ }^{12}$ Newman 2005.

${ }^{13}$ Wrathmell 1980.

${ }^{14}$ Tarlow 2007, 16.

15 James 2003; McFarlane 2004; Horning 2012b; RCAHM 1992.
} 
${ }^{16}$ Frazer 1999; Symonds 1999; Orser 1996. Numerous authors have raised concerns about the potentially totalising nature of narratives of capitalism employed in historical archaeology, including Pedro Funari 1999, Laurie Wilkie and Kevin Bartoy 2000, Gavin Lucas 2006. See discussion in Horning 2011, and in Croucher and Weiss 2011.

${ }^{17}$ Dalglish 2005, 262.

18 Johnson 1993; 1996.

${ }^{19}$ Crawford 1969.

${ }^{20}$ Mitchell 1881

${ }^{21}$ Breen 2012

22 Mrozowski 1999; Horning 2006a and b.

${ }^{23}$ Breen 2012, Horning 2013.

${ }^{24}$ See Mrozowski 2014 for an extended discussion of doing history backward in relation to interpretations of archaeology and capitalism. For the Ulster Plantation and the Ards, see Horning 2013; O'Keeffe 2008.

${ }^{25}$ Orser 1996; Croucher and Weiss 2011.

${ }^{26}$ Mehler and Gardiner 2013

${ }^{27}$ Verhaeghe 1997, 28.

${ }^{28}$ Bateman 2004.

${ }^{29}$ Bloch 1953 [1944].

${ }^{30}$ Eg Friedman 1999 and his 'Golden Arches' theory of international relations.

${ }^{31}$ Scholte 2000, 15-16

${ }^{32}$ The literature on globalization is vast and disparate. Influential works on contemporary globalization include Friedman 1999 while considerations of the deeper roots of globalization can be found in Moore and Lewis 2009 and Chandra 2007. Useful overviews of globalization include Scholte 2005, Osterhammel and Petersson 2005, and Steger 2010; while Cooper 2001, 2008 explicitly considers the interrelationship of colonialism and globalisation.

${ }^{33}$ Moore and Lewis 2009, 4-7. Scholars of the ancient world have objected the ways in which Moore and Lewis impose contemporary terms such as 'chief executive' upon past economic roles, seeing the effort as fundamentally ahistorical and an endeavour to 'modernize' the past. See for example Morley 2011.

${ }^{34}$ Wallerstein 1974. As noted by Johnson in 2006 that 'the work of Wallerstein on world systems theory....has not had any discernible effect on European historical archaeology.'

${ }^{35}$ Pendery 1999, 74.

${ }^{36}$ Moussette 2009, 43.

${ }^{37}$ For selected examples of how archaeologists are challenging assumptions about one sided colonial equations, see Schmidt and Walz 2007, see also contributions in Schmidt and Mrozowski 2013, and in Ferris, Harrison and Wilcox 2014.

${ }^{38}$ Helms 1988, 2-33.

${ }^{39}$ Helms 1988, 18-19.

${ }^{40}$ Killock et al. 2005, 6-16.

${ }^{41}$ For object biography, see Gosden and Marshall 1999; Kopytoff 1986, Apparadurai 1986, Hoskins 1998.

${ }^{42}$ A considerable body of literature exists exploring the active nature of objects and how objects become things. See Olsen 2010 for an explication of thing theory, and Hodder 2012 on the entanglement of people and things.

${ }^{43}$ Straube 2013. For the Jamestown excavations more generally, see contributions in Post-Medieval Archaeology volume 40/1, 2006.

${ }^{44}$ Building on Taussig's 1993 conceptualisation of mimesis.

${ }^{45}$ Turpin 2015, 265-267; see also Macgregor 2007. Powhatan's mantle consists of constructed of four deerskins decorated with shells that depict a human, two animals, and over thirty circles (generally interpreted as the political units within the paramount chiefdom); Kopytoff 1986.

${ }^{46}$ Cooper 2005, 93.

47 Sikes 2008.

${ }^{48}$ Horning 2012a; Tracey 2015.

${ }^{49}$ Gaimster et al. 1990, 15-16.

50 Lucas 1998, 76-80.

51 Bloice 1971, 150-151.

${ }^{52}$ As discussed explicitly by Maxine Berg 2007, 44-45. See also Barker 1999. 
${ }^{53}$ The seminal anthropological discussion of consumption remains Douglas and Isherwood's 1979 study The World of Goods which brought together economic and cultural perspectives on consumption. For postmedieval Europe, Bourdieu's classic work Distinction remains influential in his exploration of the entanglement of consumption and elite power, while de Vries' more positive read on the engagement of all social classes with consumption is sympathetic to the perspective of Daniel Miller $(1987,2005,2010)$ regarding the active ability of individuals to employ objects in identity-making.

${ }^{54}$ Berg 2007, 40-42; de Vries 2008, 44-45

${ }^{55}$ For example see the individual contributions in De Munck and Lyna 2014.

${ }^{56}$ de Vries 2008, 55

${ }^{57}$ For example, Miller 1987.

${ }^{58}$ See Dixon 2011; Moshenska 2014.

${ }^{59}$ Wilson 2008, 152.

${ }^{60}$ See Crosby 1972; 2004 for explication of the Columbian Exchange. Jared Diamond's controversial 1999 study, Guns, Germs, and Steel has been readily picked up and cited by globalization scholars (eg see Steger 2013) but we would argue it is far too deterministic in its portrayal of the influence of the Columbian Exchange.

${ }^{61}$ Boivin et al. 2012, 463.

${ }^{62}$ Svizzero and Tisdell 2015, 13.

${ }^{63}$ This point was also made strongly by Matthew Johnson 2006, 324-325, but the situation in terms of research within the United Kingdom has not significantly changed.

${ }^{64}$ For example, the 2011 special issue of the journal (Post-Medieval Archaeology volume 45/1) dedicated to Bermuda includes several articles which address slavery. Crewe 2012 considers the meaning of abolitionist messages on ceramics in nineteenth-century Sheffield.

${ }^{65}$ Webster 2015. This study is part of a larger research project exploring the archaeology of the Atlantic slave trade, and complements the recent shift in maritime archaeology towards addressing the salve trade and its material signatures following on from a critique levied by Fred McGhee in 1998 and 2007. See also Flatman 2003.

${ }^{66}$ Mrozowski 2010, 119.

${ }^{67}$ Brown; Bowen 1994; Bain and Prevost. 28.

${ }^{68}$ Fothergill 2014.

${ }^{69}$ Armitage 1981; Games 2006, 2008.

${ }^{70}$ Hickman 2014.

${ }^{71}$ Brooks 2009.

${ }^{72}$ Schweickart 2014, 407

${ }^{73}$ Cooper 2001, 206

${ }^{74}$ Millar 2001, 258; Brooks and Rodriguez 2012, 84. Matthew Johnson 2006, 318, also addresses the issue of scale in post-medieval archaeology.

${ }^{75}$ Crossley 1967, 66

${ }^{76}$ Muldrew 1993, 177.

${ }^{77}$ Smith 2005, 87

${ }^{78}$ Comaroff and Comaroff 2005, 178

${ }^{79}$ Eg. Belford 2010

${ }^{80}$ Dixon 2011.

${ }^{81}$ Scholte 2000, 47-48; Graves-Brown 2013, 252

${ }^{82}$ Funari, Young and Fazzeli, Mizoguchi 2010, Horning 2016. 